\section{DISCOURSE ON THE THAI NATION BY PROGRESSIVE INTELLECTUALS FROM THE 1950's - 1960's}

\section{Sopha Chanamool ${ }^{1}$}

\begin{abstract}
A discourse on the Thai Nation by progressive intellectuals in Thailand during 1950's-1960's is discussed. During this period they formed a narrative, and a new meaning of "Chat Thai" or Thai nation. The progressive intellectuals, such as Malai Chupinit, Sod Kuramarohit, Assani Ponlachan and Chit Phumisak, debated a new meaning of national identity. They described the Thai Nation differently to the previous elite groups, such as King Rama VI in the 1920's and Luang Wichitwatakan in the 1940's. King Rama VI wrote about the great ancient kingdom of Sukhothai. Luang Wichitwatakan expanded on that to show the greatness of the Thai nation since ancient times, and also that the Thai race was shaped from a pure race and had a unity of Thai culture. Conversely, the progressive intellectuals argued that the Thai nation was not shaped from a pure Thai race, and also that it did not have a unity of Thai culture. According to them the Thai nation was formed from ethnic heterogeneity and cultural diversity. Their ideas a bout the communities which made up the Thai nation held that Thai people from different regions have their own cultures (their own historical background, their own local languages, their own way of life), which are different to the central
\end{abstract}

\footnotetext{
${ }^{1}$ Ph.D., Department of History, Faculty of Arts, Chulalongkorn University
}

Thai culture. Furthermore, they recognised the importance of all Thai people, regardless of class, and the minority ethnic groups in shaping the Thai Nation.

\section{Introduction}

The old concept of 'nation' seems to face criticism in the modern world, which has been affected by globalization. Since the concept of the nation state emerged in many Asian countries during the 18th century, nations were created with respect to borders and geo-body. ${ }^{2}$ These countries not only identified themselves with the new idea of modern geography but they also identified themselves with their origin. In this way, the concept of nation-states involved the integration and centralization of themselves with autonomous power.

In response to the view of some western groups during the colonial period that Thais were barbarian, the concept of "Chat Thai" or Thai Nation was produced by Thai elite groups in the early $20^{\text {th }}$ Century. At that time King Rama VI wrote the narrative of Thai History in his work, 'Thiaw Muang Phra Ruang' (Travel to Phra Ruang's City), which described the Golden Age in Sukhothai, the first Kingdom of Siam (Thailand). (see Mongkudklaochaoyuhao, 1967). After the 1932 revolution there was no change to this idea or this narrative even though the absolute monarchy had ended. Challenging this idea of Thai History was Luang

\footnotetext{
${ }^{2}$ The word 'geo-body' used with the meaning of nation was used with respect to modern geography. For more detail, please see Thongchai Winitchakul 1994. Siam Mapped: The Geo-Body of the Nation. Honolulu: University of Hawaii Press.
} 
Wichitwatakan in Phibunsongkram's government (1938-1944 and 1948-1957). He employed the concept of "Chat Thai" in a new narrative in which the Thai nation was shaped from a pure Thai race and there was a long history of the Thai kingdom since ancient times. The Kingdom of Nanchao, in southern China was described as the first kingdom of Thai History. Later, this group of Thai immigrants from the south of China to 'Suwannaphum' or the "Golden Peninsula" settled the kingdom of Sukhothai, and then Ayutthaya and Rattanakosin which are part of modern Thailand. Therefore, the plot of Thai History was a narrative employing the concept of a pure Thai race and the harmony of Thai identity.

In this paper, I would like to argue that there is a discourse surrounding the narrative of Thai national i dentity, which was constructed by the mainstream ideology until the 1950's. At that time, Thai progressive intellectuals, most of them journalists in magazines such as Aksonsan, Siamsamai and Pituphum, were against the ideals of the government of Field Marshal P. Phibunsongkram. They also debated the plot of Thai History and went against the theories of the elite groups. The new narrative of the 'Thai nation' presented by progressive intellectuals had two meanings. Firstly, that the nation had formed from ethnic heterogeneity as well as from cultural diversity. Secondly, that the economy of the Thai nation was formed for the people and supported the people, rather than being concerned only for the government.

I will present the new analysis of the 'Thai nation' from progressive intellectuals, such as Malai Chupinit (1906-1963), Sod Kuramarohit, (1908-1978), Assani
Ponlachan $(1918-1987)$ and Chit
Phumisak (1930-1966).

\section{The Plot of Thai National Identity by Elite Groups}

King Rama VI (King Wachirawut), who had many pen names for writing, such as Aksawaphahu, and RamChitti, began to explore Thai History when he traveled to Nakorn Prathom and was inspired to investigate the plot of Thai History. $\mathrm{He}$ began to clarify the meaning of "Chat" or 'nation' from the point of view of language, meaning that Thai people must speak Thai. He wrote the article "Khwam Pen Chat Doi Thae Ching" (The Real Thai Nation) in 1915, and he expected to form the real nation as follows:

"The vocabulary of this "nation"
has been translated in many
ways, and each way should be
corrected to form one national
language. However, that is not
the end of the debate as to
whether it should be called a real
nation because each language
forms a different character of the
nation"

(Aksawaphahu, 1977: 71-72)

At that time, the challenge to the nation state was the Chinese movement in Thailand which opposed the role of the Manchu Dynasty in China and also opposed the Japanese who tried to capture China. The activity of the Chinese in Thailand, which was called 'look jin nai Siam' (meaning Chinese who were born in Thailand) was trouble for King Wachirawut and he thought it might affect the stability of his throne (see Tejaperi, 2001 and Murashima, 1996). Tejaperi's work mentioned the political situation of King Wachirawut: 
"For the Siamese Government, the peculiar trouble with these lookjin communists was that they were in a legal sense "Thai" and hence could not be easily expelled. It was the National Act of 1913, a legal invention of none other than the arch-anticommunist King Wachirawut himself, which, while furnishing the government with the power to banish Chinese and Vietnamese communist immigrants, precluded deportation of the arrested lookjin communists, for it claimed as Thai "every person who was born on Thai territory"

(Tejaperi, 2001: 22).

We can see that the creation of an official nation began during the reign of King Wachirawut, but the concept was not concerned with the people's rights or freedom. There were three main themes which King Wachirawut considered to represent the Thai identity; loyalty to King, loyalty to religion and loyalty to nation. In addition, he attempted to make the monarchy the focal point of Thai nationalist sentiment. However, he appears to have met with early difficulties as well. The King began by noting that the kingdom contained a growing number of people who felt compelled to pass judgment on the government and its policies. He added that there was nothing necessarily wrong with this in that it signified that people were coming to perceive the country as being their own. The problem was said to lie with the fact that most people still lacked a "true understanding" of national affairs (Copeland, 1993: 34).

During his reign of about 15 years, laws were passed to assist the building of the nation, such as legal nationality, legal surname, compulsory primary schooling and the e stablishment of the "Wild Tiger Corps" (Kong Suea Pa). The Wild Tiger Corps was the controversial para-military organization he established at the beginning of his reign. This organization is generally held to have provided the monarchy with a forum for disseminating his ideas to the officials of the realm (Mongkudklaochaoyuhao, 1962). In this way, the official nationalist discourse that King Wachirawut articulated and set in place in the context described above can be seen as a particular expression of things like 'selective tradition'. Barme said in his thesis that in the case of King Wachirawut, the 'selective tradition' involved a delineation of the nature of 'Thai' identity, together with an explication of the slogan 'Nation, Religion and King' which had first been articulated at the end of the nineteenth century. These ideas were first made public in a series of speeches the king made to the Wild Tiger Corps (Barme, 1989: 26).

Therefore, the concept of 'Chat Thai' or 'Thai Nation' has been further developed by state ideology since it's creation by King Wachirawut. Later, following the commencement of the Phibunsongkram government in 1938, this period was influenced by the nationalism policy. A key player in the development of this policy was Luang Wichitwatakan. In the latter period, it is argued that he was instrumental in formulating an official notion of Thai identity on behalf of the military-dominated state, and helped to have this deployed on a broad scale via the media and through the expanding school system.

Luang Wichitwatakan (1898-1962) was from a Chinese family background and he was given the Chinese name 'Kimliang'. 
However, in his speech for his uncle, 'Somdet Phra Wannarat' (Heng Khemmachari), at Wat Mahathat, the place where he gained priesthood, he claimed to refuse his relationship to the background of this fellow:

"As my lineage I can count to be the nephew of Somdet and live close to h is house. S ince I w as born I never saw Chinese people in his house. The special tradition in Uthaithani at this time is if the parents have Thai names then the children must have Chinese names. My father's name is In and my mother's name is Klai which are Thai names. My father was a novice Buddhist, never respected the $C$ hinese $\mathrm{G}$ od and e verything about him is Thai. Anyway, I was given a Chinese name while my younger sisters and brothers were given Thai names. When I went to Europe and then returned I found that they had changed their names to Chinese. It seems the Chinese influence in Uthaithani is strong..." (Wichitwatakan, 1989: 11)

So when he grew up he had changed $h$ is name to Thai, as 'Wichit Wichitwatakan'. In later life, after he had become a renowned Thai nationalist figure, Luang Wichitwatakan denied this part of his heritage and was adamant that he had come from pure Thai stock. He achieved a great deal since he was a novice at Wat Mahathat by learning foreign languages, including English and French and also by reading foreign books. After he left the monkhood he found a job at the Ministry of Foreign Affairs while he studied part time at Law School. In 1920 he went to France to take on a position of clerk at the
Thai Embassy in Paris. At that time, he went back to study law again at the University of Paris. He then continued his studies in Political Science when he moved to work in London, England. (Wichitwatakan,1989: 3-5)

From his life in the West, Luang Wichitwatakan's ideas regarding the history of civilization and progress and personal development were influenced by the concept of history there. In looking at the latter aspects of his work, it will be shown that although Luang Wichitwatakan was supportive of the royalist administration, the support he offered was not without a degree of criticism (Barme, 1989: 35 ). A s he was a good reader, he had an ambition to hold a position at the Thai National Library. He wrote in 1930 “...the highest position that I prefer in my life is a commander of the Thai National Library..." (Anonymous, 1963: 41)

Luang Wichitwatakan had worked in government service as Minister of Foreign Affairs from 1918 to 1933 , and he then achieved the position of Director of the Arts Department in the new Ministry of Education. In 1934 this position gave him responsibility for the Thai National Library, as had been his goal. He then went to work as a politician for Phibunsongkram's government in many ministries, such as the Ministry of Education, Ministry of Foreign Affairs, Ministry of the Treasury-House and Ministry of the Economy. Moreover, he was also posted to the Thai Embassies in Japan, India, Switzerland, Austria and Yugoslavia. Meanwhile, Luang Wichitwatakan took this opportunity to develop a writing career. He became involved in the movement of capital into the publishing business after he solicited a series of private loans and established the 
Wiriyannuphap Printing Company in October 1927. The creation of this enterprise put him in a position to ensure that the texts he produced would be published, and that he would receive guaranteed payment for their sale. It also gave him an opportunity to promote writers with whom he was friendly and shared similar views. (Barme, 1989: 40)

For his work in history, Luang Wichitwatakan wrote Thai history using the plot of race in formulating the identity of the Thai nation. His important publication was Siam and Suwannaphum (Siam and Golden Peninsula) which was published in 1933. Many years later at the University of History he gave lectures titled 'Ngan Khon Khwa Ruang Chat Thai' (Searching for the Thai Nation) and 'Kham Banyai Prawattisart Thai' (Lecture for Thai History). He not only wrote fictional texts based on Thai history, but also produced narrative Thai history, such as his novel Leaud Suphan (Suphan's blood), in which he demonstrated the bravery of the villagers in the Ayutthaya period by describing how they fought the Burmese troops. This novel was very popular for people to perform as a play. There were three concepts to the main plot of the Thai Nation which appeared in his work. Firstly, the concept of the 'Great Man', secondly the concept of the 'Great Pure Thai Race' and thirdly, the concept of a 'Great Thai Kingdom in the Past'. Reynolds argued that "...The concept of the 'Great Man' theory of history, which is indispensable to the motif of national liberation, seems to me notable not as a legacy of royalist historiography, in which the monarchy is the most important actor, but as a paradigm common elsewhere at the time..." (Reynolds, 1992: 324). The work of Somkiet Wantana (Wantana,1986) argued that the historiographical style of
Luang Wichitwatakan was by and large a conservative one, trying to emulate the success of others, such as Prince Damrong. This style changed after 1932. Direct involvement in national political life during the post 1932 period made him turn to King Wachirawut's intellectual heritage and away from that of Prince Damrong. In Wattanatham Sukhothai (Sukhothai Culture), he adopted King Wachirawut's overview of Thai history by quoting a long passage from Thiaw Muang Phra Ruang. Contrary to his earlier beliefs his ideological position now moved toward a 'radical right' or somewhat fascist tradition. (Wantana, 1986: 307-308)

Although the ideas of Luang Wichitwatakan seem to back tradition, he also played a role in bringing a modular form of nationalism from Europe. Reynolds mentioned that Luang Wichitwatakan constructed the pure ThaiBuddhist paradigm from the dominant ethnic group. He also made Sukhothai the earliest site of this pure Thai-Buddhist society; 'pure' both in terms of ethnic dominance and in terms of social structure. (Reynolds, 1992: 324)

However, Luang Wichitwatakan worked to distinguish the Thai nation and he tried to identify a form of 'Thainess' during the 1930 s-1950s. I would like to discuss how his ideas differed over 3 decades. Firstly, in the 1930s, he described how Sukhothai was the founding civilisation of Thailand, such as in his works Searching for the Thai Nation and Siam and Golden Peninsula. He took advantage of his work as director for the Fine Arts Department by researching and learning history, archeology, liberal arts, fine arts and culture. He said "khong di khong chat" (National heritage) was combined to form the identity of the Thai nation; "...each 
nation should be a real nation and must have their own fine arts which can be distinguished from others... different groups of people who can characterise themselves by their high culture..." (Wichitwatakan, 1932: 20; 1936: 66)

In the second period during the 1940 s, he constructed a 'national culture' by integrating the diverse cultures of all people from many regions, including the North, Northeast and South. This stage built a sense of historical consciousness, or 'Thainess'. As in his novels and plays, he pointed out that all people from the North and the South are Thai. Examples are Suek Thalang (Thalang War), a story of the people of the South, and the northern stories, Chaoying Saenwee (Princess Saenwee) and MahaThewi (Great Queen). At that time Luang Wichitwatakan could use official media (radio) because he was employed as President of the Committee for 'Ratthaniyom' (Ratthaniyom was created in Phibunsongkram's government) in the Ministry of Education. During this period he promoted a generalization which constructed Thai identity as a more simplistic stereotype rather than being complex. He also changed the division of multi-culture and multi-ethnic groups to become a unity. Moreover, he tried to construct a representation of 'Thainess' or real Thai by creating a new meaning of 'Thai'. He put forward a new concept of empires, which was his dream since the 1940's, to explain the Ayutthaya kingdom in the period of King Naresuan. $\mathrm{He}$ appreciated Sukhothai culture because it taught people to be diligent in merchandising, construction and fighting. (Wichitwatakan, 1939: 18)

Thirdly, in the 1950's, after the Second World War, the situation for Thailand changed because it returned to being a 'small country', rather than a great kingdom as Phibunsongkram and Wichitwathakarn had dreamed of building before the 1940's. In addition, Thailand feared the power of communism that had influenced Indo-china, North Korea and China. In particular, Thais feared the Communist party of China, which won power in 1949. They felt that Thailand should withstand the power of communism, just as Luang Wichitwatakan had been against communism since the 1930's. He supported four factors as role models for the Thai nation. One of them was "Not to be Communist" (Wichitwatakan, 1989: 6). He preferred to defend the Thai nation from communism and considered 'nationalism' the best way to protect Thailand. He suggested that:

“...Nationalism is the only way to fight and prevent communism.... there is no way to go against communism; the best way is to remind us to always think of 'Chat' (nation). If we can build nationalism the same way as communism is built, we should not fear that communism will capture our country..."

(Wichitwatakan, 1989: 158)

This issue encouraged Phibunsongkram's second period of government (1948-1957) to attempt to jail some intellectuals and politicians who were opposed to its antiCommunist policy. For most of his life, Luang Wichitwatakan seemed to focus his work on construction of a new narrative of the Thai Nation. Conversely, the 1950's was the time of booming critical intelligence, and there were some progressive intellectuals who taught a different motif of nation and gave a new version of the Thai nation. They were 
inspired to be liberated from their own Thai masters, and a narrative that seemed increasingly out-of-date with Thailand's political and economic realities. Before attempting to understand the concepts of these intellectuals, I would like to explain the world situation as it affected Thailand during the 1950's-1960's.

\section{The Relationship of Thailand to the United States and the changing situation in Southeast Asia after the Second World War}

After the Second World War, there were so many changes around the world. For example, there was independence from the West's colonial power for many countries in the w orld, a nd a lso the transactions of power of Western countries; from Western Europe to the United States of America (USA) and the Union of Soviet Socialist Republics (USSR). These countries became powerful during the $20^{\text {th }}$ Century while arguing the political doctrines of democracy (USA) and communism (USSR).

The expansions of power between the USA and the USSR increased their alliances with other countries and resulted in confrontations in many parts of the world; Asia, Latin America as well as Europe. Specifically, Vietnam and Korea were geographically (north and south) and politically (democracy and communism) separated into two sections by the respective intervention of the USA and the USSR. The northern Vietnam and Korean territories w ere communist a nd s upported by the USSR, while South Vietnam and South Korea became democracies and were influenced by the USA's support.

The USA occupied Vietnam after the defeat of France in Vietnam, in the battle of Dien Bien Phu. The French withdrew their troops from Vietnam in 1954 in accordance with the Geneva Treaty (see Duiker, 1981: 160-168). The people of North Vietnam, led by Ho Chi Minh, announced their independence from France. This made the USA anxious about the expansion of power of North Vietnam, obviously supported by the USSR, to other Southeast Asian countries (see Osborne, 1995: 154-173). Similarly, North and South Korea were separate countries when North Korea invaded South Korea in 1950. In response to that invasion, the USA sent its army to protect $\mathrm{S}$ outh $\mathrm{K}$ orea. D ue to the alliance of Thailand with the USA, Thai soldiers were sent to fight in this war.

Apart from the rallies for independence in the Philippines, Indonesia and Burma, the USA was apprehensive about an invasion of Southeast Asian countries by the USSR. In particular, the USA was also concerned about the communist party of China, led by Mao Se Tung, which overthrew the old regime to become the Republic of China in $11^{\text {th }}$ October 1949. Also a matter of concern was the intervention of South Korea by North Korea in 1950. These alarming events consequently led to the USA implementing offensive policies.

As a result, the USA through necessity had to seek alliances in order to retard the spread of communism. Thailand was the most interesting country to the USA for such purposes. This was because of its geography, since Thailand is centrally located amongst other countries in this region. Also, Thailand had never been colonized by a foreign power which was thought to make political negotiations easier. During this post-war period, Thailand was struggling after considerable defeats against Japanese troops via the role 
of the Free Thai movement. This organization opposed and undermined the Japanese troops in Thailand during the Second World War. The Free Thai Movement had its command center in both the USA and England. They did little actual fighting against $J$ apanese troops in Thailand, though they greatly assisted the Allies in the underground subsidiary tasks of intelligence gathering, communication and transportation, hiding and helping Allied secret service officials, rescuing and protecting Allied POWs and nationals, and sabotaging Japanese war supplies and installations. Pridi Phanomyong, as a leader of the Free Thai Movement, conferred with the Allies to declare that the relationship between Thailand and Japan during World War II was invalid and that Thailand was not defeated as the Japanese were. This declaration was supported by the USA. Then the USA negotiated its alliances to assure the status of Thailand after the war, such as encouraging Thailand to be a member of the United Nations. For these reasons the relationship between Thailand and the USA tightened after the Second World War. Subsequently, there was the first treaty mutually signed in 1950 which designated support for Thailand in educational, cultural, economic and academic areas in return for the use of 'facilities and areas' of Thailand by the USA, so that army bases could be established (National Achrive, 1950). In 1954 a military contract and cooperation was developed which led to the first military base of the USA, named JUSMAG, being established.

(National Achrive, 1954)

As a consequence of the Thai-US collaboration, Thailand obtained wide varieties of assistance from the USA. From 1951-1956, the USA gave economic support to Thailand valued at approximately US\$ $100,000,000$ as seen in the following report:

"The aid program is designed to assist the effort of the Government of Thailand in the following key areas, which are crucial to development in all other spheres of the economy: expansion of transportation, power, and communications; improvement of basic public services to Thailand's people in health, education, agricultural extension, and stimulation of industry; and modernization of overall government budgetary procedures and fiscal management in order that Thailand may achieve most effective use of its resources. Under the terms of the 1950's agreement between Thailand and the USA, this program of aid was set up to work cooperatively like a partnership to assure that the efforts and materials put into it are most effectively used for the welfare of the Thai people."

(ARPA, No. 04100)

The affiliations and cooperation between Thailand and the USA were maintained from the second period of Phibunsongkram's government until the era of Field Marshal Sarit Thanarat, another Prime Minister of the Thai government. Thanarat overthrew Phibunsongkram in the military coup of 1957.

However, the context of international politics post Second World War had a significant influence on Thai politics. The role and power of Phibunsongkram subsided. As well as Phibunsongkram, Luang Wichitwatakan and other members 
of h is g overnment w ere to be charged a s war criminals. However, they were freed from such allegations under the "War Criminal Law Act" of the Thai government, $8^{\text {th }}$ October 1945. In April 1946, the Supreme Judicature of Thailand declared "that the War Criminal Law Act which regulated the provisions of punishment, were against the Thai Constitution, and therefore invalid". (Kasetsiri et al, 1997: 1)

As such, this provided the opportunity for Phibunsongkram and his colleagues to return to power and authority. At the same time, Pridi Phanomyong and his Free Thai Movement organization, which battled against Japan and its allies during the Second World War, also backed Thai politics. Some members of the Free Thai Movement organization became Members of Parliament (MPs). These MPs, such as Thong-in Phurithat, Thawin Udon, Tiang Sirikhan and Chamlong DaoRuang were called the Isan MPs or the left wing of the Free Thai Movement. They were from the Northeast region of Thailand. (Tejaperi, 2001: 78-79). From 1945 to 1947, owing to the abrogation of the Anti-Communist Act in 1946 and the leftist inclination of the Pridi/Free Thai governments, the Communist Party of Thailand (CPT) operated freely and openly. However, from 1948 to 1952 , with the fall of the Pridi/Free Thai group and the return of the authoritarian Phibunsongkram regime, they had a more difficult political life. (Tejaperi, 2001: 93). Later, they were arrested because of the Kabot Wang Luang or the Grand Palace rebellion and they were executed". 2

${ }^{2}$ Please see Kasetsiri, Chanvit and Thamrongsak Petchlert-Anan (eds.). 2001. Pridi Banomyoung and 4 Isan Ministers +1 . The Foundation for the Promotion of Social Sciences and Humanities Textbooks Project and Thammasart Archives
Pridi Phanomyong became Prime Minister for a considerably short period (March 24 - August 23, 1946). His adversaries later claimed that he was behind an assassination attempt on King Rama VIII. The $8^{\text {th }}$ November 1947 coup forced Pridi Phanomyong to leave Thailand but he tried to r eturn to p ower with the coup in $26^{\text {th }}$ February 1949, (the so-called "Kabot Wang Luang"; see Saisen, 1989). This event was supported by the Thai Royal Navy. Nevertheless, this rebellion failed, Pridi escaped but could never return to the Kingdom of Thailand. He stayed abroad until he died. Even though, a group of Thai Naval officers tried to stage a second coup, called "Kabot Manhattan" (Manhattan's Rebellion), this incident was also unsuccessful. (see Sukrongphang, 1986)

Regarding such political situations in Thailand, the Thai government and in particular Phibunsongkram's second government had to cooperate with the USA. During this period, Phibunsongkram implemented the anti-communism policy, which could suppress people whom he considered his adversaries, not just politicians but intellectuals such as journalists and writers. Specifically, intellectuals were charged with rebellion against Phibunsongkram, known as 'Kabot

Project. The MPs from the Northeast, such as Tieng Sirikhan and Thongin Phurithat, were alleged to have tried to separate the 1 and in the Northeast to join Indo-China as they had relationships with the leaders in Laos and Ho Chi Minh. For this movement of building a network of nationalists in Southeast Asia, please see Gosha, Christopher E. 1999. 'Thailand and the Southeast Asian Network of the Vietnamese Revolution, 1885-1954, Curzon Press. and Van Hoan, Hoang. 1988. Revolutionary Reminiscences, A Drop in the Ocean, Foreign Languages Press, Beijing. 
Santiphab' (Peace's Rebellion), in the $10^{\text {th }}$ November 1952. (see Katithammanit, 1992). The intellectuals who were arrested were mostly journalists such as Kulap Saipradit (editor of Suphapburut), Supha Sirimanon (editor of Aksonsan) and Plueang Wannasri (editor of Pituphum).

In the next section, the roles of the intellectuals, who influenced concepts of discourse with a new definition and identification of the 'Thai nation', will be discussed. This occurred during the 1950 's in response to the tense situation between Thailand and the USA and stalemate in the relationship between Phibunsongkram's government and its opponents, who were officially called 'the Thai enemies'.

\section{Discourse on the Thai National Identity by Progressive Intellectuals during 1950's-1960's}

Before detailing the salient roles and critical thinking of Thai progressive intellectuals, I would firstly like to provide some profiles of the four intellectuals that I selected for discussion in this paper. Namely, Malai Chupinit, Sod Kuramarohit, Assani Ponlachan and Chit Phumisak. ${ }^{3}$

${ }^{3}$ There are several progressive Thai intellectuals, e.g. Kulap Saipradit, Supha Sirimanon, Senee Saowapong and Thaweep Woradilok, who have interesting concepts. However, I intend to discuss only four persons (Malai, Sod, Assani and Chit) concerning the aim and objectives of this study. These persons and their writings are considered individually unique. I have selected some aspects of their work to analyze. For example, the articles of Malai Chupinit, the novels of Sod Kuramarohit, the verses of Assani Ponlachan and the historical studies of Chit Phumisak. The writings of these 4 progressive Thai intellectuals are considered to clearly reflect

\section{Background of Thai progressive intellectuals}

Malai Chupinit (1906-1963)

Malai Chupinit was a thinker and writer for his entire career. He was a serious journalist and writer, devoting his life to his work. He began his career as a teacher at Wat Saket School after he graduated from Suankulap Wittayalai School. However, his desire to be a writer inspired him to resign from this official job before his two-year assignment was completed.

Malai was born in April 25, 1906, at Tambon Klong Suanmak (currently Amphor Nakorn Chum) in Khamphaengpet province. His parents were wood entrepreneurs (particularly teak wood). They distributed their products to Nakornsawan province via wooden rafts. These images were mirrored through his work in his novel named, "Thung Maharat" (Great king field) (see Sukniyom, 1989: 19; Riam-aeng, 2000). Malai attended primary school in his hometown. Afterwards, he moved to Bangkok and he finished his six year high school course. He then enrolled to study for a teaching certification at Wat Bowonniwet School. Later, he returned to finish his high school level at the same school, Suankularb Wittayalai. While he studied there, he also studied an intensive English course at Thepsirin School where there were many students who became famous journalists and writers, such as Sod Kuramarohit and Kulap Saipradit. They were good friends from the time they studied together until they graduated and worked as journalists (Na Bangchang, 1993: 13).

the "Thai nation", which will be discussed in detail in the next section. 
Malai started his journalism career as an editor of Thai Ti (southern Thailand) newspaper, in Songkhla province in 1926. One year later, he returned to Bangkok under the persuasion of Kulap who resigned from Bangkok Kan mueang (Bangkok's politics) newspaper. Malai continuously worked with several newspapers, such as Suphapburut (Gentleman), Thaimai (New Thai), Prachamit (People's friend) and Siamsamai (Age of Siam). These involved a wide variety of w ritings, such a s life-style, love stories, political events and historical novels.

Malai was simultaneously an editor and writer of articles, features and bypaths of knowledge. He was regarded as a leading novelist. He wrote several kinds of novels, such as 'Longprai' (Jungle trip) with his pen name 'Noi Inthanon'. This novel depicted his true experiences in jungle expeditions and explorations. Malai had several pen names for his writings (articles, features and novels). He passed away from lung cancer in 1963. In this study, only his articles written during the 1950's will be discussed and some of these will be selected to discuss regarding the aspect of 'Thai nation'.

\section{Sod Kuramarohit (1908-1978)}

Among progressive Thai intellectuals, it could be said that the biography of Sod was different from the other intellectuals. This may be because Sod graduated in China during the Republic Period. This also made his attitudes and concepts of writing toward communism differ from other progressive intellectuals. Although this is true, Sod is still considered a progressive Thai intellectual because of his 'anti-ruler' attitudes and his alternative thinking.
Sod was born on $27^{\text {th }}$ April 1908. He came from a wealthy family, his father being a high level officer, who was once a governor and his mother was of Chinese lineage (Kuramarohit, 1961: 1-3; 1966: 1). $\mathrm{He}$, himself, was the most outstanding student while he was studying at Thepsirin School. Subsequently, he applied for the King's scholarship to study in England. Unfortunately, he failed, even though he applied for the King's scholarship twice. Afterwards, he decided to study law and, in 1928 , he was awarded a scholarship from the Ministry of Education to study in China. The purposes of this scholarship were to educate a person who would then oversee Chinese schools and their curriculums in Thailand. At that time, the government was anxious about the influence of Chinese people in Thailand.

Sod studied at the National University of Beijing in Chinese linguistics, literature and history. After he graduated he wrote many novels and features which concerned several aspects of China. Examples are Pakking Nakon Haeng Khwam Lang (Memories of Beijing), Xing Fei, Phunum Kabuankan Chin Mai (Xing Fei, The leader of new China) and Kabuankan Seri Chin (The Free Chinese Movement) (see Jeemteeraskul, 1991; Tejaperi, 2001). In 1936, Sod returned to Thailand and started his career as an official in the Ministry of Education. After working for 10 years, he resigned from $h$ is p osition b ecause he felt that he could not solve national problems. $\mathrm{He}$ moved to Prachinburi to work as a farmer and to manage the Cooperation project which assisted farmers in negotiating with the government and industry. However, the project was unsuccessful. Later, he moved to Chonburi province and established a foundation called, "Munnithi Banrai Phandin Thai" (Foundation of Thai Farm and Thai Land) 
for helping the poor people through a project named "Krongkan Burana Chonnabot" (Rural Reconstruction Project). Once again, he failed to complete this project and establish the foundation. He was also a candidate for the Farmer's Party at one time. Nevertheless, he never had a true political life. In 1978 he passed away from the effects of diabetes (Nakasart, 1976: 6-7); (see also Maneerod, 1976: 32). Like his close friend, Malai Chupinit he left several writings.

Sod began his writing at the age of 12 , when he was taught by his father to write verses. When he was studying at Thepsirin School, he participated in writing for the school magazine, in the section Thalaengkan Thepsirin (Announcement of Thepsirin). Most of his writings were verses. $\mathrm{He}$ and his classmates published a school newspaper called, Darunsan (Youth Message). He was also responsible for writing novels and translating. Meanwhile, he took part in art, copywriting and cartoon drawing. Before going to study in China, he started writing short stories, myths, fiction and translating. These were published in the newspapers; Senasueksa (Military study) and Thai Kasem (Happy Thai). While he was studying in China, he wrote political articles, which were published in Prachachat (Nation) newspaper. From the time he began writing political articles, Sod was under suspicion of the government. When he came back to Thailand, he consistently wrote and published material in several newspapers and magazines. During 19461947, he and his colleagues established "Chakkawat Sinlapin" (Artists Empire). His most salient writings were novels, some of which will be discussed in this study. Most of his works critical of the Thai government were published under his pen name, 'Barbara', in Piyamit (Friendly) magazine. These works expressed his opinions on national economics.

\section{Assani Ponlachan (1918-1987)}

Assani was a progressive Thai intellectual who might be regarded as radical or left wing (Ponlachan, 1998: 88). After he resigned from government office in 1952 he moved to many countries such as China, Vietnam and Laos as a member of the Communist Party until his death in 1987. Then in 1997, there was an effort to bring his bones back to Thailand.

Assani was born on $15^{\text {th }}$ September 1918 , in Ratchaburi province. He grew up in a noble family, like Sod Kuramarohit. His father was an officer and of royal hereditary through the governor of Kanchanaburi during the early years of the Rattanakosin period. The surname of his father has been hereditarily used as the surnames of these families: Ponlachan, Phonlakul, Phonlatorn and Wongsarot. His wealthy family enabled him to receive a good education, and he started at a boarding school in his hometown and then studied high school level at Suankulap Wittayalai School, Bangkok. Next he became a law student at Thammasart University and he graduated in 1940. He was then an officer in the Department of Public Prosecution, Ministry of the Interior. For his duties, he was appointed to Pattanee province. In 1944 he was moved to Saraburi province due to intelligence reports of the Thai government that he supported the Malaya rebels who were fighting with Phibunsongkram's government.

Assani's official duties were difficult for him. This was probably because of his absolute honesty and the fact that he refused to undertake wrong or immoral assignments from his superiors. 
Subsequently, his position was unduly reshuffled. At that time he had many friends, such as Plueang Wannasi, who was one of the progressive intellectuals of that time. Most of his writing colleagues had major roles in rallies against the Government. This caused increasing trouble for Assani in his official position, and finally he resigned in 1952. From 1953 to 1957 he studied Marxism in Bejing. After his return to Thailnd in 1958, he became editor of Saithan (see Buason, 1998: 231-233).

Assani was an intellectual during the 1940's-1950's. Like other intellectuals mentioned previously, he started his writing activities while he was a student, at both Suankulap Wittayalai School and Thammasart University. His writings were published in Aekkachon and Prachamit journals, which were purposely against the government. This made the security of his life relatively vulnerable, and due to this, Assani had several pen names. He wrote several articles from either political or academic aspects, which concerned the areas of language and literature. He boldly criticized some royal literary works. For example, he appraised the writing of King Wachirawut. Assani's usual writings were verses, which were published in several journals (i.e. Saithan and Siamsamai) under his unique and famous pen name 'Nai Phi'. One of his verses, titled 'Duean Phen' (Fullmoon), has been composed as a song. It has been sung and played in several versions by numerous artists, and is alternatively called 'Kidthueng Ban' (Missing Home). In this study, serious verses of Assani will be further discussed in the following section.

\section{Chit Phumisak (1930-1966)}

Chit Phumisak is the youngest intellectual discussed in this study. He was born on 25th September 1930 in Prachantakam district, Pracheenburi Province, to a middle class family. His father was a clerk of the Excise Department and his mother was a housewife. When his parents separated and divorced, his mother and older sister raised him. When he grew up, he moved to stay with his family in many provinces as his father was officially shifted for his work, including Pratabong province (now a province of Cambodia). There, he learnt Cambodian or Khmer language (Mitr Raumrob, 1976: 23-24). $\mathrm{He}$ also studied the Cambodian historical records (Manuscripts) intensely. Chit returned to Bangkok and he studied high school level at Triam Udom Sueksa School. Afterwards, he studied for his BA. At Faculty of Arts Chulalongkorn University. When he was studying at the university, he was the editor of the university journal. Controversial articles written for this $\mathrm{j}$ ournal caused a ggressive reactions from conservative individuals. Some students threw him downstairs, known as 'Yonbok'. Following this incident, the university suspended him for one year. He then worked for Thaimai newspaper and he also worked as a guide for visitors to Angkor Wat and Angkor Thom in Cambodia. Later, Chit returned to his studies and he graduated in 1957. $\mathrm{He}$ became a lecturer at Petchaburi Teaching College and a guest lecturer at Silapakorn University (see Art and Culture for Life Group, 1986; 1987). He simultaneously studied a Master's degree at the Academic Institute, Prasarnmit campus, Bangkok.

In the meantime, Chit wrote and published several articles in many journals. His works under several pen names were about language, literature, art and translation 
(such as the socialist novels of Maxim Gorky). However, the masterpieces of his work were academic, with particular regard to etymology. He applied his expertise in etymology to develop a new concept in Thai historical writings. The most important of such works are 'Thai Society Along the Chao Phraya River before the Ayutthaya period' and 'The legends of Siamese, Laotian and Khmer words as well as National Names Regarding Societies Characteristics: Facts of the People of Khmer'. These will be discussed in detail, in the next section.

Chit was the most recognized intellectual during the 1960's-1970's. His biography and writings considerably influenced Thai youths at that time. During the 1970's, Chit was raised to hero status, as someone who inspired young people to seek out their lives and not become obsolete. Consequently, there was strong public criticism of politics and society. Some argue that this led to an upheaval, called the 14 October 1973 incident, which saw the collapse of the Thai g overnment of F ield Marshal Thanom Kittikhachon. Another theory is that the years after Chit's death were a period of change for young people. Thus a researcher who studied Chit's life and works, mentioned that:

“...Chit was closer in educational background, and his life had the added meaning of a martyr's death. Moreover, the search for his biography and the discovery of his work between 1973 and 1976 were part and parcel of unearthing a kind of cultural excavation of Thailand's literary and cultural history after the Second World War..." (Reynolds, 1987: 15)
Chit was charged and jailed for being labeled a communist, according to the Communist Act that Field Marshal Sarit Thanarat upheld. When he was released from prison he was determined to join the Communist Party of Thai (CPT). As a consequence of this decision, he was shot and died in Sakol Nakorn province in May 1966.

\section{Reconstruction of the Thai Nation by Progressive Intellectuals}

As previously mentioned, the first two sections of this paper were about concepts of the elite group regarding the "Thai Nation' in the writings of King Wachirawut and Prince Damrong on absolute monarchy and also Luang Wichitwatakan and P. Piboonsongkram in the 1940 's. The political atmosphere and the international situation after the Second World War have also been discussed. These events affected the attitudes of intellectuals during the 1950's-1960's towards the government, which led to reaction against state power and governing policies, and finally to reaction against the concepts of 'Thai Nation'. In the 1950's1960 's the progressive intellectuals had similar concepts with few differences. These attitudes were relatively different from past decades. It seems they were reconstructing a new meaning of 'Thai Nation'.

The analyses of essays in this study are implemented partly with the concepts of Hayden White. He explained how writing styles, such as metaphor, plot and emplotment can be in the form of tragedy, comedy, romance and satire (see White, 1973; 1987). The writing styles of the four intellectuals depicted significant changes in Thai society. They wrote about changes of historical plot and about various groups of 
people such as nobles, kings, heroes, marginal people (lower society persons, farmers and labourers) and ethnic groups, like L aotian, Khmer and $\mathrm{K}$ aren. $\mathrm{C}$ hanges in Thai society were apparent in the 1970's, and Reynolds and Hong, reported how various groups, such as farmers, 1 abourers and rebels were affected during turning points in Thai history (Reynolds and Hong, 1983: 77-104). However, it cannot be denied that the works of intellectuals during the 1950's-1960's influenced ways of shaping and explaining Thai society by writers during the 1970 's-1980's. For example, the reports of Thongchai Winitchakul concluded that Thai historical literacy changes occurred following the $14^{\text {th }}$ October 1973 event, as since that time it urgently wanted a new history and this stage gave it the opportunity to reconstruct the work of Marxism in the 1950s (Winitchakul, 1995: 6).

In this study, 'discourse' will be defined by three forms of intellectual publications, implying that there were three forms of discourse in regard to 'Thai Nation'. The first discourse correspondences are about 'Thai Nation' in terms of 'historical plot'. The second are detailed as 'national economy' and the last are shown as 'power of the state'.

Firstly, the discourses about 'Thai Nation' which appeared in the Thai histories against the attitudes of governing persons were bravely acknowledged to be the work of Chit Phumisak. In this study, his three articles chosen were: 'Thai Society along the Chao Phraya River before the Ayutthaya Period', 'The Legends of Siamese, Laotian and Khmer Words as well as National Names Regarding Societies Characteristics: Facts of the People of Khmer' and 'The Real Face of Thai Feudalism Today' (Phumisak, 1957:
356-491). The first two articles were assumed to be written by Chit while he was in jail from 1958-1965. The other acknowledged $\mathrm{T}$ hai s ocieties, which h ave developed within five areas: ancestry, slavery, privilege, capitalism and socialism areas. To such an extent, Chit's methods of analysis were considered Marxist. Although many academics criticized his methods as not appropriate for Thai society, his articles had a relatively high impact on Thai history. Historians had to consider historical events in the context of solemn discussions about reigns of kings, monarchies and kingdoms. These defined the 'Thai Nation' merely in terms of the roles of the kings. As a result of Chit's book, 'The Real Face of Thai Feudalism Today', there were several debates about the meaning of 'sakdina' (Feudalism). For example, Reynolds suggested that Chit used the word as a metaphor for 'rebellion', as he said that “...this mention of privileges did not itself provoke the arrests, but the sentence illustrates how the term 'sakdina' now belongs to a discourse aimed at subverting the proper meanings of such legitimizing institutions as the monarchy and the Buddhist m onkhood..." (Reynolds, 1987: 150).

Meanwhile 'Thai Society a long the Chao Phraya River before the Ayutthaya Period' and 'The Legends of Siamese, Laotian and Khmer Words as well as National Names Regarding Societies Characteristics: Facts of the People of Khmer' might be relevant to each others. In these articles Chit argued that the main points of 'Thai Nation' analyzed by King Wachirawut and Luang Wichitwatakan were that Sukhothai was the first kingdom and Ayutthaya was the second. King Wachirawut's method of analysis considered straight line historical plot and this emphasized the chronology 
of historical events, with the basis being the history of the monarchy. This commenced after the people of Sukhothai emigrated to the south and later formed their own kingdom. In contrast to this basis, Chit argued that this did not provide the authentic development of communities and groups of people, because of the nation states concepts. Chit also mentioned that it was incorrect to solely follow the monarchy basis:

"...when stated about the Thai histories, stories of Sukhothai and Ayutthaya were generally pinpointed. However, there was no discussion on information of Thai societies in other parts of Thailand. For example, the northern Yonok kingdom and others were much longer in their histories than the southern kingdom"

(Phumisak, 1983: 8-9).

Thereafter, while Chit tried to compose 'The Legends of Siamese, Laotian and Khmer Words' and 'National Names Regarding Societies Characteristics: Facts of the People of Khmer', his concepts were more and more crystallized into diversities of races, their settlements on the land, called 'Laemthong' (Golden Pennisula), as well as their reciprocal reactions. 'Siam' itself has many meanings, for somehow it means land and/or nation without specifying citizenship. Chit's presentation procedures were based on etymology and linguistic contexts since languages were one of the outcomes of societies and cultures. Regarding his interest in the history of words, it could be said that Chit scrutinized the identity of 'Thai' via tracking and tracing the word 'Siam'. Accordingly, it helped Chit to discover the root of 'Thai'. Therefore, the searches for 'Siam' or 'Thai' might be deemed as the procedure for seeking the 'subject' of 'Nation,' or the so-called search for the identity of the 'Thai Nation' (see Winitchakul, 1991; Smart, 1985 and Wongyannawa, 1990).

In conclusion, Chit revived the old historical plots with his two methods. Firstly, he denied the mirage in which the 'Thai Nation' is one state having a relatively long history as a proficient and civilized kingdom, from Nanchao until Sukhothai and Ayutthaya. Secondly, he argued against the historical plots which attempted to unitie all races to be one, such as in the work of Luang Wichitwatakan in the 1940's. Luang Wichitwatakan mirrored the development of today's 'Thai Nation', which w as e volved from s everal groups or races of people. Thus, 'Thai National Identity' has recently progressed from cultural diversities of individual localities to blend together to become Thai culture. On the whole, this is the first discourse of Thai history written by Chit.

The next article discussed is Sod Kuramarohit's novel, Raya, which he wrote during 1955-1956 (see Kuramarohit, 1970). During this period, he also wrote and published his works in the column named 'Banrai Phandin Roa' (Our land and farm), in Pituphum journal. $\mathrm{He}$ proposed his concepts about 'The National Economic Project' and his ideas were about principles of cooperation which he thought might be appropriate for the Thai economy. There were mountains of responses and opinions from readers. However, he was warned by the Department of Police about the content of his articles, and he was asked to send them for pre-checking by the police before being published. Sometimes he also had to report in person to the department. Sod started his 'Rural Refurnishment' project, 
in Pracheenburi province and there he grew straight bamboo shoots. However, he failed because he did not respond to the militarily corrupting power and price tyrannizing from middlemen (Nakasart, 1976: 71). These were parts of his experience depicted and detailed in his novel 'Raya'.

Raya was the name of a character who is a general member of the public. However, he was intimidated and was taken advantage of by a merciless local merchant. This merchant was enabled to do illegal business by illegal powers through his relatives, one of whom was a politician of national rank. When Japanese troops invaded Thailand, Raya and other villagers fought against the troops together with the Free Thai movement. Coinciding with writing this novel, Sod pointed out how to struggle against Phibunsongkram's government. $\mathrm{He}$ also argued against the Nationalism policies officially created by Luang Wichitwatakan using several media: the educational system, radio broadcasting, songs and drama. Sod scorned Luang Wichit's methods through his Raya characters as follows: “... Thai Nation was already impressed into our hearts, quietly, profoundly and naturally. Kao Thamon (Thamon mountain) people didn't say how we love our nation, however we did. We didn't sing all day and all night to embolden our hearts..." (Kuramarohit, 1970: 919)

As mentioned previously, Sod resigned from his official job to be a farmer. While working on his fields, he was close to other farmers and perceived their poverty: lack of social welfare and infrastructure, and mistreatment by middlemen and financial agents. These were ideal subjects for his 'Raya' novel. One

character, who was a member of the Free Thai Movement, graduated from abroad and visited 'Thung Takra' (Basket field). There, he felt that Thailand still had plenty of fertilized and unoccupied lands. $\mathrm{He}$ encouraged the villagers of 'Thung Takra' to form a cooperation (sahakorn), in which he dreamt that they would equally share their lands and work cooperatively, described as follows:

\begin{abstract}
“...having a cooperation for stopping money squeezing... everyone will own one's land, will have machines to support one's work, will have markets to sell and not have to wait for middlemen to take advantage... will have money to build a school and a hospital as well as roads. Children go to school without paying tuition fees and patients are freely cured without medical and prescription charges..."
\end{abstract}

(Kuramarohit, 1970: 544-545)

Sod's concept of a cooperation (sahakorn) stemmed from his own authentic experiences, from which he believed the communist system was not suitable for Thailand. However, he considered it better than capitalism. The reasons why Sod argued against communism were because when he was in China, he found bloodshed and violence. Besides, a small group of people had the power to govern and control the whole country. Meanwhile, Sod stood out against capitalism as he thought that such a system

- was self-oriented, which aimed solely for profits regardless of morality. Capitalists tried to take advantage without concern for others. With his serious experiences in price tyrannizing, Sod fought against financial backers and middlemen and he also alleged that the politicians practiced 
corruption with foreign investors. To his mind all of them were 'national robbers'. Sod mentioned that "...I do believe that destruction of our nation has occurred from such national robbers who are publicly honored" (Kuramarohit, 1970: 1197)

Considering the political situation during Phibunsongkram's government during the 1950 's, in which the government eradicated the powers of Pridi Phanomyong and his colleagues, Field Marshal Phibunsongkram dictated the governing power of the state. Field Marshal Phibunsongkram also delegated his powers to three groups of his trusted colleagues. The first group was headed by General Phao Sriyanon, Head of the Department of the Police, who exploited governing power for his group's prosperity. The second was the group of Major General Phin Chunhawan and the last w as the group of a rmy G eneral S arit Thanarat. These groups, cooperating with financial backers, and businessmen, handled and controlled the state enterprises and banks (Suwannathat-Pien, 1995: 192-239). However, a faction led by Sarit Thanarath eventually staged a coup against Field Marshal Phibunsongkram in 1957. Therefore, the images of corrupted leaders were depicted and detailed through the articles of progressive intellectuals. Intellectuals criticized the Thai government policies, particularly on the nation's economy, which was the basis of nationalism and led to the establishment of state enterprises. The state enterprises resulted from political and economical increments of the government, through joint ventures with international firms. In the editorial of Pituphum, 10 September 1956, the government was urged to give up its contracts with the US and English oil companies. Such contracts were signed after World War II in which Thailand had to sell oil solely to Shell oil company (England) and Standard Welcome Oil Company (USA), as a consequence of Thailand holding the status of a defeated country from the war. This editorial stated that:
"...the oil case is a tangible way to fight for the perfect independence of our nation. To abandon contracts providing opportunities for Western fascists to monopolize oil and to abandon contracts regarding land leases with the West. The West's power has enabled them to rob us of many properties and assets. Return of these assets would be our path to independence and equality..." (Wannasri, 1956)

For the intellectuals at that time, the critiques of the economy then became a new concern for the economic aspect of 'Nation'. The intellectuals opposed capitalism and fascism, since they thought that these were used by more powerful countries to override lesser ones. Sod subsequently thought that Thailand must have a good economic plan, like the unsuccessful economic proposals of Pridi Phanomyong. Sod proposed that principles of cooperation were required to solve the nation's problems. He tried to implement 'National Rural Refurbishment' projects. It might be said that his national communities were 'Thai rural style', and he imagined that communities of the Rural Refurbishment would be a way to refurbish the nation. Sod always thought that cooperation was a good way for the country to survive encroachments on its sovereignty and it could be used in national economic policies for lessening the poverty of the 
Thai people. After the events of $14^{\text {th }}$ October 1973, Sod still entertained his concepts and ideas and he wrote a letter to the Prime Minister (Sanya Thammasak), stating 'how we could solve our national problems' instrumentally with principles of cooperation. In fact, such ideas and concepts of Sod's were absolutely about new economic management, since the economy is the concrete fundamental basis of politics, in which everyone is equal.

The last two intellectuals, Malai Chupinit and Assani Ponlachan, will be discussed simultaneously. Analysis of Malai will be primarily through his editorials in Siamsamai journal, and analysis for Assani will be through his verses, which were partly published in Aksonsan and Siamsamai. Additionally, other examples of their works will be mentioned and discussed at the same time.

Malai and Assani are alike in that they wrote in metaphoric contexts regarding the 'Thai Nation'. They also criticized the images and strategies of the 'Thai Nation' which the government tried to create. Considering their writing styles, however, it can be argued that theirs were totally different in terms of tone and presentation. Malai's w ere s imple but impartial, which may have been influenced by his prior experience as an editor. Meanwhile Assani's contained fantasized words, such as metaphors, implications and satires. The nature of writing verses provided him with opportunities for using whimsical words. Nonetheless, his works sometimes tended to be aggressive.

Issues which Malai criticized of the ruling party included American-oriented policies, particularly in regard to sanction policies on other countries, such as North Korea.
Malai mentioned in the editorial of Siamsamai that:

"Though the war on the Korean peninsula has been fought for a long time, do not expect that it will continue indefinitely who might tell how severe it will be after those two powerful sides, either the westerners or reds, have clashed with each other. Modern weapons will be used and new strategies of mass destruction will be implemented to fight for victory at any cost" (NL, 1955. Sobo. 6.4.1/4).

Malai's experiences of the horrors of war encouraged him to publish articles in Siamsamai which promoted good relations with Thailand's neighboring countries, such as positive features on Burma after the Second World War. Malai acknowledged the concerns about the 'Thai Nation' through a metaphoric article interpreting the 'Thai Nation' as:

"...not only this meaning of Thai, however, means the Thon dancing of the northeast, it means the 'Rong-Ngeng' and the ' $\mathrm{Ma}$ $N o-R a$ ' plays of the south, it means northern dances called 'Maeng Tub-Tao'... since orders, traditions and customs, which will lead whatever nation to have its own identity, are symbols and signs of Thai cultures".

(NL, 1955. Sobo. 6.4.3.2/2).

Malai mentioned that the identity of the 'Thai Nation' includes the ownership of this nation, in that everyone equally has rights to own this country, regardless of who you are: farmers, millionaires, ministers or prisoners. He also insulted the officially appealing procedures of 
devoting and sacrificing for the nation, which appeared though several media. Examples were the practices of respecting the Thai flag and singing the national anthem at set times, and learning the historical dramas of Luang Wichitwatakan's 'Power of Sacrifices'. Malai said "...love for the nation for some Thais might merely start and stop by singing the national anthem...efforts to be an authentic nation is not dependent on devotion as an actor in the drama". This was the way that Malai used to pay back Luang Wichitwatakan. At the same time, he also argued against attempts to unite Thais to be unique, as shown by his article published in Prachamit-Suphapburut, as follows:

"Journeying to every region of the kingdom of Thailand, during the past 20-30 years gave me a myriad of lessons and feelings to understand how to live mutually and together on this land... while this is true, many persons who are interested in the history, races, cultures and lifestyles of our people have tried and done the same as myself, which is to understand geography and the differences of people. These persons are my human friends who together live on the same land; Nation of mine"

(NL, 1955. Sobo. 6.4.3.2/2)

To such an extent, Malai's concepts were similar to Chit's in that they showed differences and diversities of people and cultures. These acknowledged the 'Thai Identity' regarding 'Ethnic Nation-State', rather than a proposal of civil society. The journalistic and writing lives of Malai were threatened several times by state power. His newspaper was suppressed and he was investigated by the police.
Due to his polite characteristics and nonpolitical activism, similar to Kulap Saipradit and Plueang Wannasri, Malai avoided being charged and arrested (Teerawanit, 1983: 85-92).

Like Malai, Assani wrote under pen names. He began to write articles in the journals 'Aekkachon Raaisubda' (Private weekly) and 'Siamnikorn' during the 1940's and in 'Siamsamai' and 'Aksonsan' in the 1950's. His most famous pen name was 'Nai Phi' (Mr Ghost), which implied satires of the dictatorship during this period. $\mathrm{He}$ composed a verse which acknowledged the darkness of the nation's dictatorship, using the imaginary of complete darkness.

$\mathrm{He}$ also explained who 'Nai Phi' (Mr Ghost) was as follows:

\footnotetext{
"'Nai Phi' not being a ghost as ghostly assumed using 'Nai Phi' not as its name but being Shiva, who with three eyes, my friends, being a mysterious shield from the evil of man."

(Ponlachan, 1998: 83, 85).
}

Assani used verses as satire to imply that Thailand was in a dark era, due to misuse of power by Field Marshal Phibunsongkram. The reason why Assani used the pen name 'Nai Phi' might be that he needed to conceal himself during rallies against the government. Besides, this name might be the third eye of the Shiva (the name of a Hindu God), which keeps itself for purposes of evil or badness (it has been believed that if this eye were opened everything would be absolutely burned). Moreover, 'Nai Phi' might stem from one verse, 'Whom the Ghosts love, lives not!' Plueang Wanasee, a close friend of Assani, sometimes published works in Aksonsan and Pituphum under the pen 
name 'Nai Sang', which was similar to 'Nai Phi'.

In summary, Assani's verses apparently criticized the government; however this was done discretely in the form of satire. In one verse, Assani acknowledged Thailand during the 1950 's to be a patient infected by governmental diseases:

"until Siam was ill, it needs to be healed giving magic pills might cure it but worsening beyond endurance the wrong pills will weaken hearts"

(Ponlachan, 1998: 144)

Regarding his verse 'Lab Therd Chao Thai' (Let's sleep, Thai people) (Ponlachan, 1998: 195), Assani made sarcastic comments inferring that Thai people would prefer to sleep rather than wake up and face misused powers: 'Through opening eyes people are frightened by machine guns, policemen's chase to dissect and destroy". Another example, 'sang yang phi phi' (Built by ghost) mentions:

"Siam has its fame as the golden country

Siamese proudly declare their sovereignty

However our homes and houses are built insanely

Like house without crossbeams...

Dwellers, day and night living in pain"

Like other intellectuals, Assani sharply criticized the policies of the government and he also fought against the spread of the 'Great Man' sect, as mentioned in the verse 'Hero and Heroism,' which persuades Thais to fight against this sect.
Assani offended the dictatorship of the government by writing verses; however his concepts were not different from other intellectuals at that time. He pointed out that the 'Thai Nation' was like a badly ill patient because of the dictatorial toxins present since the transformation of the Thai political system in 1932. Thai people hoped that the 'Thai Nation' would be the ideal system, in which people are the major components of 'Nation'. Eventually, the system became a dictatorship hidden under a veil of democracy. The rulers attempted to cajole their people into obeying their power so that the nation could be successful. They chanted their motto 'Obeying the leader and fending off all national dangers'. Thus, the Thai progressive intellectuals desired to present their own and new 'Thai Nation' discourses, which were opposed to those broadcasted by the government.

\section{Conclusion}

In regard to the discourse of the "Thai Nation,' there are two paths which go against each other; the mainstream built by nobles in the absolute monarchy and government during Phibunsongkram's era, and the alternative built by progressive intellectuals in the 1950's. While the nobility and government tried to build a Thai Nation according to a plot of Thai history which was continuous from ancient times to the present and was composed of a unique Thai race, progressive intellectuals in the 1950 's-1960's tried to give a new idea that the Thai nation was shaped from a diversity of ethnic groups. For the first group, Thai nationhood meant to be loyal to the King a nd to o bey the g overnment, and conversely, the second group argued that Thai nationhood is based on independence and is autonomous. Finally, the contrast in the concepts of these groups 
in regard to the economy of the Thai nation was that progressive intellectuals accounted for the importance of poor people and went against the elite groups who exploited government power for their prosperity. The discourse of progressive Thai intellectuals was represented in several kinds of writings such as academic texts on Thai history, political articles novels and verses.

\section{References}

Aksawaphahu (Mongkudklaochaoyuhao, Prabatsomdet, Phra). 1977. True Nationhood. Bangkok: Ruamsan.

Anonymous. 1963. Remembrance book for Luang Wichitwatakan, Volume 2. Published in remembrance of the funeral of General Luang Wichitwatakan. Phranakom: Ratchadaromkarnpim.

ARPA Research and Development Center. Document No. 04100. United States of America Operations Mission in Thailand. Thai-American Economic Cooperation 1951-1958. Bangkok: Chulalongkorn University.

Art and Culture for Life Group. 1986. Legend of Chit Phumisak. Remembrance book for the $3 I^{s t}$ anniversary of his death: Chit Phumisak. Bangkok.

Art and Culture for Life Group. 1987. The Original Legend of Chit Phumisak. Remembrance book for the $31^{s t}$ anniversary of his death: Chit Phumisak. Bangkok.

Barme, Scot. 1989. Luang Wichitwatakan: Official Nationalism and Political Legitimacy Prior to World War II. Master of Arts Thesis, Australian National University, Canberra.

Bouson, Vieng-Vashira. (ed.). 1998. Life and Work: Legend of 'Nai Phi' (19181987). Bangkok: 21st Century Company.
Bradley, William L. and Chunacheep Chinwanno (ed.). 1992. The Route of Power and Documents of Foreign Policy of America in Asia. Bangkok: Tula Ltd.

Chupinit, Malai. (Ream Aeng). 2000. Maharat Field. Bangkok: Bannakit.

Copeland, Philip Matthew. 1993. Contest Nationalism and the 1932 Overthrow of the Absolute Monarchy in Siam. Doctoral Thesis, Australian National University, Canberra.

Duiker, William J. 1981. The Communist Road to Power in Vietnam. Colorado: Westview Press.

Gosha, Christopher E. 1999. Thailand and Southeast Asian Network of the Vietnamese Revolution, 1885-1954. Nordic Institute of Asian Studies Monographic Series No. 79. Curzon Press.

Jeemteeraskul, Somsak. 1991. The Communist Movement in Thailand. $\mathrm{PhD}$. Thesis, Department of Politics, Monash University, Australia.

Kasetsiri, Chamvit and Thamrongsak Petchlert-Anan. (ed.). 2001. Pridi Banomyong and 4 Isan Ministers +1 . Bangkok: The Foundation for the Promotion of Social Sciences and Humanities Textbooks Projects.

Kasetsiri, Chamvit, Thamrongsak PetchlertAnan and Wikan Pongpanitanon, (ed.). 1997. Recording of the Seminar for Field Marshal P. Phibunsongkram for Modern Politics. Bangkok: The Foundation for the Promotion of Social Sciences and Humanities Textbooks Projects.

Katithammanit, Wiwat. 1992. Peace Rebellion. Bangkok: Khobfai.

Kuramarohit, Sod. 1961. My Mother's bibliography. Phranakorn: Raumsam.

Kuramarohit, Sod. 1966. The Survival of Human Life. Phranakorn: Piriyakit. 
Kuramarohit, Sod. 1970. Raya. Vol 1-5. Bangkok: Phanfa Pitthaya.

Manirod, Adul. 1976. The political concepts of Sod Kuramarohit. Masters Degree Thesis, Political Sciences Faculty, Chulalongkorn University, Bangkok.

Mit Raumrob. 1976. Bibliography of Chit Phumisak. Auksornsart Picharn. 12.3: 23-24.

Mongkudklaochaoyuhao, Prabatsomdet, Phra. 1962. Selected Majesty's Speeches of King Rama VI. Published in remembrance of the funeral of $\mathrm{Mr}$. Manu Sanitwong Na Auytthaya on the $14^{\text {th }}$ October 1962.

Mongkudklaochaoyuhao, Prabatsomdet, Phra. 1967. Travel Phra Ruang City. Bangkok: Sinlapakam.

Murashima, Eiji. 1996. Sino-Siamese Politics: The Overseas Chinese Political Movement in Thailand, (A.D. 19241941). Chinese Studies Center, Institute of Asian Studies, Chulalongkorn University, Bangkok.

Na Bangchang, Khinittha. 1993. During the life of Malai Chupinit. Bangkok: Damrongsit.

Nakasart, Kuson. 1976. The Life and the Literature of Sod Kuramarohit. A Thesis submitted to the Arts Faculty, Chulalongkorn University, Bangkok.

NL.1950. Motho. (1) 3.15.18/2. The Agreement for the Cooperation in Military between Government of Thailand and Government of the United States of America. 20 October, 1950.

NL. 1954. Motho. (1) 3.1.5.18/1. The Committees for Agreement in Military Support between Thailand and the United States of America. 15 March 1954.

NL. 1955. Sobo. 6.4.1/4. The Private Documents of Malai Chupinit (Selected editors of Siamsamai).
NL. 1955. Sobo. 6.4.3.2/2. The private Documents of Malai Chupinit in "PS." By Malai Chupinit on Prachamit and Suphapburut.

Osborne, Milton. 1995. Southeast Asia: Introduction to History. S ixth Edition, Allen \& Unwin.

Phumisak, Chit. 1957. The Real face of Thai Feudalism Today. Nitisart: Welcome to a New Century. 7: 4.

Phumisak, Chit. 1983. Thai Society along the Chao Phraya River before the Auytthaya Period. Bangkok: Maingam.

Phumisak, Chit. 1992. The Legends of Siamese, Laotian and Khmer Words as well as National Names Regarding Societies Characteristics: Facts of the People of Khmer. Bangkok: Kledthai.

Ponlachan, Assani. 1998. Collection of Verses, Literature Studies: Assani Ponlachan. Bangkok: Samanchon.

Reynolds, Craig J. 1987. Thai Radical Discourse: The Real Face of Thai Feudalism Today. Southeast Asia Program. Cornell University, Ithaca.

Reynolds, Craig J. 1992. The Plot of Thai History. In Wijeewardene, Gehan and E.C. Chapman (ed.) Patterns and Illusions of Thai History and Thought: In Memory of Richard B. Davis. Institute of Southeast Asian Studies, Singapore.

Reynolds, Craig J. and Lisa Hong. 1983. Marxism in Thai Historical Studies. Journal of Asian Studies 43:1.

Riam-aeng (Malai Chupinit). 2000. Maharacha Field. Bangkok: Bannakit.

Saisen, Pratheep. 1989. The Grand Palace Rebellion and the Situation of Pridi Phanomyong. Bangkok: Aksonsan.

Smart, Barry. 1985. Michel Foucualt. London and New York: Routledge.

Sukniyom, Suthira. 1989. Malai Chupinit and his writings. Bangkok: Seangdao. 
Sukpeng, Niyom. 1986. Navy Officers 'Manhattan' Revolution. Bangkok: Matichon.

Suwannathat-Pien, Kobkue. 1996. Thai Wartime Leadership Reconsidered: Phibun and Pridi. Journal of Southeast Asian Studies 27:1.

Suwannathat-Pien, Kobkue. 1995. Thailand's Durable Premier Phibun Through Three Decades 1932-1957. New York: Oxford University Press.

Tejaperi, Kasian. 2001. Commodifying Marxism; The Formation of Modern Thai Radical Culture, 1927-1958. Kyoto: Center for Southeast Asian Studies.

Trirawanit, Sukanya. 1983. Thai Newspapers from the Revolution in 1932 to the Revolution in 1973. Bangkok: Thai Wattanapanit.

Van Hoan, Hoang. 1988. Revolutionary Reminiscences. A Drop in the Ocean. Beijing: Foreign Languages Press.

Wannasti, Plueang. $1956 . \quad$ Editorial. Pithuphum. 10 September 1956.

Wantana, Somkiet. 1986. The Politics of Modern Thai Historiography. Doctoral Thesis, Department of History, Monash University, Melbourne.

White, Hayden. 1973. Metahistory. Baltimore: The John Hopkins University Press.

White, Hayden. 1987. Topics of Discourse: Essays in Cultural Criticism. Baltimore and London: The John Hopkins University Press.

Wichitwatakan, Luang. 1932. Daungpratheep. 2,36 .

Wichitwatakan, Luang. 1936. Speeches for the Fine Arts Department. Speech for Local Govemors at the Fine Arts Hall on the $8^{\text {th }}$ June 1936. National Library, Bangkok.

Wichitwatakan, Luang. 1939. Sukhothai Culture. Speech at Department of
Promotion, Phranakom: Krom Khosanakam.

Wichitwatakan, Luang. 1989. Nationalism. On the Anniversary of the $100^{\text {th }}$ year of General Luang Wichitwatakan: Selections of his Bibliography and his Articles Published on the Occasion of his birthday and the Anniversary of the $100^{\text {th }}$ year of General Luang Wichitwatakan. August 11, 1989. Bangkok: Sangsan Books.

Winitchakul, Thongchai. 1991. The Methodology of G enealogy. Report of Research for Curriculum of Liberal Arts Faculty, Thammasart University, Bangkok.

Winitchakul, Thongchai. 1994. Siam Mapped: The Geo-Body of the Nation. Honolulu: University of Hawaii Press.

Winitchakul, Thongchai. 1995. The Changing Landscape of the Past: New Histories in Thailand Since 1973. Journal of Southeast Asian Studies. 26:1.

Wongyannawa, Thanet. 1990. The Analysis of Subject, Theory without Theory for the Power of Michel Foucualt. Research Center for the Political Sciences aFaculty, Thammasart University, Bangkok. 